\title{
First Measurements of the Earth's Electric Field at the Arctowski Antarctic Station, King George Island, by the New Polish Atmospheric Electricity Observation Network
}

\author{
Marek KUBICKI ${ }^{1}$, Anna ODZIMEK ${ }^{1}$, Mariusz NESKA ${ }^{1}$, \\ Jerzy BERLIŃSKI ${ }^{2 *}$, and Stanisław MICHNOWSKI ${ }^{1 *}$ \\ ${ }^{1}$ Institute of Geophysics, Polish Academy of Sciences, Warszawa, Poland; \\ e-mail: swider@igf.edu.pl (corresponding author) \\ ${ }^{2}$ Faculty of Electronics and Information Technology, \\ Warsaw University of Technology, Poland \\ *emeritus
}

\begin{abstract}
Atmospheric electricity measurements are performed all over the globe for getting a better understanding of the processes and phenomena operating in the Earth's electric atmosphere, ionosphere and magnetosphere. Over recent years, we have established coordinated observations of atmospheric electricity, mainly of the vertical component of the Earth's atmospheric electric field, from Polish observation stations: Stanisław Kalinowski Geophysical Observatory in Świder, Poland, Stanisław Siedlecki Polar Station in Hornsund, Svalbard, Norway, and, for the first time, the Henryk Arctowski Antarctic Station in King George Island. The organisation of this network is presented here as well as a preliminary summary of geophysical conditions at Arctowski, important from the point of view of atmospheric electricity observations. In particular, we refer to the geomagnetic observations made at Arctowski station in 1978-1995. We also present the average fair-weather diurnal variation
\end{abstract}

Ownership: Institute of Geophysics, Polish Academy of Sciences

(C) 2016 Kubicki et al. This is an open access article distributed under the Creative Commons Attribution-NonCommercial-NoDerivs license

http://creativecommons.org/licenses/by-nc-nd/3.0/. 
of the atmospheric electric field based on observations made so far between 2013 and 2015 .

Key words: atmospheric electricity, observation network, Arctowski Antarctic Station, geomagnetic activity, fair weather conditions.

\section{INTRODUCTION}

Polar regions, the Arctic and the Antarctic, have unique locations near the geographic and geomagnetic poles and due to the characteristics of their atmosphere and climate have become an important platform for atmospheric and solar-terrestrial studies (Lessard et al. 2014). International scientific events such as International Polar Years, especially the first in 1882/1883 and second in 1932/1933, and the International Geophysical Year (IGY) in $1957 / 58$ had large influence on the development of research activities in these regions by many countries, explorers and scientists. The solarterrestrial research activities in Arctowski Antarctic Station, which was open in 1977 (Rakusa-Suszczewski 1977, 1980) and named after Henryk Arctowski, the geoscientist in the Belgian Antarctic Expedition on "Belgica" ship in 1897-1899 (Machowski 1998a, b), started with geomagnetic field observations. The magnetic observation station was established at Arctowski station during the 2nd Antarctic Expedition of Polish Academy of Sciences in 1977-1978. The construction of two magnetic pavilions began in December 1977 and observations started in March 1978 (Szymański 1980). The magnetic observations have been stopped at Arctowski in 1995.

Atmospheric electricity (AE) observations in Antarctic started around the time of IGY and since then have always been part of the Antarctic scientific programme. Measurements have been made at Roi Baudoin Base, South Pole station (Cobb 1976, Bering et al. 1991, Reddell et al. 2004), Vostok (Park 1976a, Frank-Kamenetsky et al. 1999, 2001), Davis (Burns et al. 1995, Tinsley et al. 1998), and Maitri (e.g., Deshpande and Kamra 2001).

\section{ATMOSPHERIC ELECTRICITY OBSERVATIONS RUN BY IG PAS}

The Institute of Geophysics, PAS (IG PAS) and the Stanisław Kalinowski Geophysical Observatory in Świder have long traditions in the observations of atmospheric electricity. Electric field measurements were made at the Magnetic Observatory in Świder, Poland $\left(21.25^{\circ} \mathrm{E}, 52.12^{\circ} \mathrm{N}\right.$, geomagnetic latitude $\sim 50.5^{\circ} \mathrm{N}$ ) as early as the $1920 \mathrm{~s}$. As none of the pre-World War II data survived, the existing series of electric field measurements at Świder starts in 1958 (Dziembowska 2009). Nowadays, the observatory uses a wide spectrum of experimental techniques and equipment for comprehensive meteorological, aerosol and atmospheric electricity observations (e.g., Kubicki et al. 2003, 2007, 2016). The atmospheric electricity measurements include: 
the vertical component of the ground-level DC electric field using a radioactive collector and field mill method, vertical component of the density of the DC electric current (the air-Earth current) by a Wilson antenna and positive and negative air conductivity in the range of mobility of small ions, measured by a Gerdien condenser. At the Stanisław Siedlecki Polish Polar Station in Hornsund, Spitsbergen, Norway $\left(15.50^{\circ} \mathrm{E}, 77.00^{\circ} \mathrm{N}\right.$, geomagnetic latitude $\sim 73.9^{\circ} \mathrm{N}$ ) atmospheric electricity observations started in 1989 . They include measurements of the vertical component of the DC electric field and, sporadically, the DC electric current density. The electric field is measured by a rotating dipole field-mill (Berliński et al. 2007) and, independently, using a radioactive collector method. Alongside the atmospheric electricity measurements, meteorological observations are also performed automatically or by traditional methods both at Świder and Hornsund.

Land observation stations, such as Świder, especially in highly-populated areas, often suffer from high and variable pollution (aerosol), the effects of which shift the local electric field from its global diurnal pattern. The air turbulence which drives atmospheric convection current also affects the electric field (the most at local mid-day) and makes the global atmospheric electricity monitoring more difficult (Kubicki et al. 2014). On the other hand, in the polar regions, especially in the broad vicinity of geomagnetic poles, the ground-level atmospheric electric field is affected by the ionospheric convection which results from the interaction of solar wind and the magnetosphere (Dungey 1961, Park 1976b). Atmospheric observations at Hornsund, owing to its location, have been primarily set to investigate such effects, in addition to the geomagnetic observations performed there continuously since the 1980s (Michnowski 1998, Michnowski et al. 1991, 1996, 2003, 2007; Kleimenova et al. 2010, 2011, 2012, 2013; Kozyreva et al. 2007; Odzimek et al. 2011; Frank-Kamenetskii et al. 2012).

Henryk Arctowski Polish Antarctic station, King George Island, South Shetland Islands $\left(58.47^{\circ} \mathrm{W}, 62.16^{\circ} \mathrm{S}\right.$, geomagnetic latitude $\left.\sim 51^{\circ} \mathrm{S}\right)$, where atmospheric electricity measurements have not been made so far, offered an interesting possibility of investigating the DC electric field in the polar location which is not affected by anthropogenic aerosol and strong effects of atmospheric turbulence and which is sufficiently distant from the effects of ionospheric convection in the Southern Hemisphere - a valuable location for the monitoring the main (tropospheric) generator of atmospheric electricity. The advantage of this site, apart from its location in the Antarctic, was that meteorological observations have been performed there, and, besides, the level of magnetospheric disturbances could be estimated using the geomagnetic observations made at the station in the 1970-1990s.

In December 2011 we started a two-year research project set to measure and investigate diurnal variations of the atmospheric electric field and aero- 
sol at ground-level in the spatial scale extending from middle latitudes in central Europe to the Arctic and Antarctic (Świder, Hornsund, and Arctowski stations). Besides the scientific goals, our motivation for the undertaking of this project was to improve the observational capacity of the Polish observatories and to systematise and standardise the atmospheric electricity observations, starting with strengthening and extending the existing observations and transforming it into a professional scientific observational network. The created network is described in the following section.

\section{POLISH ATMOSPHERIC ELECTRICITY OBSERVATION NETWORK}

A three-site, internet-linked network of atmospheric electricity observatories has been set up, which includes the Polish Polar Station in Hornsund (HRN) in the Arctic, Arctowski Station in the Antarctic (ARC), and the Świder Geophysical Observatory (SWI) in central Poland - Fig. 1a.

The instruments at each station include:

- A system for measurements of the electric field strength near ground level. In addition to the older radioactive collector type sensors at Swider and Hornsund, new sensors have been installed. They are rotating-dipole type sensors of frequency bandwidth from 0 to $10 \mathrm{~Hz}$, and sensitivity of $2 \mathrm{~V} / \mathrm{m}$, amplitude range of $\pm 1500, \pm 6000 \mathrm{~V} / \mathrm{m}$ and output voltage $\pm 3.5 \mathrm{~V}$. The system requires $12 \mathrm{~V}$ buffer power supply (Berliński et al. 2007). Sensors are calibrated in a laboratory using a high-voltage power supply, and once a month it is short-circuit at the measurement site is in order to control the reference level.

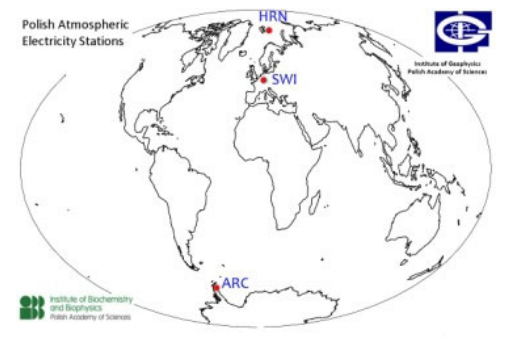

(a)

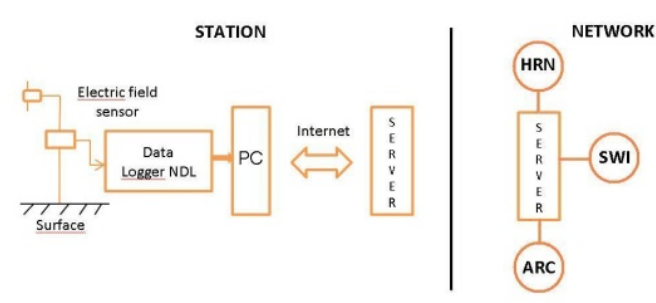

(b)

Fig. 1: (a) World map with the locations of observation stations of the Polish atmospheric electricity network: HRN - Hornsund, SWI - Świder, ARC - Arctowski; (b) Schematic diagram of the organisation of the atmospheric electricity observation network and observational data flow. Left side: organization of a single station. Right side: three-station network (HRN, SWI, ARC). 
- A data logger (NDL) with a GPS clock for the precise timing and synchronisation of the measurements in the three observation sites. The sampling frequency can be changed within the range from 0.1 to $10 \mathrm{~s}$; at present it is at $1 \mathrm{~s}$. Data are recorded on a 32 GB flash memory card. The logger has a unique IP address, allowing communication and control via internet and data download as well as current data visualisation. The data logger and buffer power supply are installed in a portable container $(0.5 \mathrm{~m} \times 1.0 \mathrm{~m} \times$ $0.6 \mathrm{~m}$ dimensions) which makes the installation and field measurements easier (Figs. $1 \mathrm{~b}$ and 3).

- In addition, for the purpose of the project, portable sensors for the measurements of aerosol concentration for aerosol size from $10 \mathrm{~nm}$ to $1 \mu \mathrm{m}$ have been used at Hornsund and Arctowski where the aerosol concentration measurements have been made for the first time. For the aerosol concentration measurements at Arctowski, the TSI 8525 model aerosol counter has been used, which measures particles of the size range from $20 \mathrm{~nm}$ to $1 \mu \mathrm{m}$ (Kubicki et al. 2016).

A dedicated software package has been designed and created for the data upload from the three observation sites to a database on a server at IG PAS. The software enables visualisation of atmospheric electricity measurements taken at the three sites. The design of the database allows incorporating data from new observation sites. The schematic diagram of the network is shown in Fig. 1b.

\section{ATMOSPHERIC AND GEOPHYSICAL CONDITIONS AT ARCTOWSKI STATION}

\subsection{Fair-weather conditions}

Weather is an important factor that affects atmospheric electricity and has to be taken into account when analysing electric field data. The fair weather conditions used in our analysis mean there is no rain, drizzle, snow, hail, fog, no local or distant thunderstorms, the lower cloudiness is less than $4 / 8(8 / 8$ is overcast), and the wind velocity is less than $6 \mathrm{~m} / \mathrm{s}$. Below we summarise the main characteristics of weather conditions at Arctowski during the atmospheric electricity observation period and we present the analysis of the number of days with fair-weather conditions at the station.

The number of fair-weather days at Arctowski is small, on average 3.4 days per month. In 2013 the number of fair-weather days was 32, and 60 fair-weather days occurred in 2015 . Over 2014 only 12 fair-weather days are registered but standard meteorological measurements have been made only during half of the year. Most fair-weather days occur in the local (Southern Hemisphere) winter season. This coincides with the time of the maximum thunderstorm activity in the Northern Hemisphere, and may be important for 
the analysis of the global (universal) signal in the electric field, since the station is more distant from the activity than the Świder and Hornsund stations are. A small number of days with little cloud cover was discussed in articles by Cygan (1981): in the period 1979/1980 (December 1979 - 17 March 1980 ) there was no cloudless days (cloudiness $<1 / 8$ ). There was only one day with cloudiness of $2 / 8$ ( 2 in okta scale $0-8$ ). The cloudiness on most days (i.e., 60 days) was 6/8-8/8. According to Angiel et al. (2010), in 2006 (January-December) there was no clear sky days, and 11 days with cloudiness less than $2 / 8$. Low clouds are the dominant cloud types, mostly with stratocumulus and stratus. Measurements during the cloudy days can be used for the studies of the cloud generator in the global circuit (Odzimek et al. 2014).

\subsection{Aerosol conditions}

An analysis of aerosol concentrations at Arctowski station is described in detail in Kubicki et al. (2016). The main and important conclusion concerning Arctowski is that natural aerosol concentrations (on most days below $1000 \mathrm{~cm}^{-3}$, average fair-weather median value $535 \mathrm{~cm}^{-3}$ ) do not have effects on the ground-level electric field, the same as in Hornsund, and contrary to Świder (where the effect of anthropogenic aerosol on the electric field takes place - see Kubicki et al. (2016).

\subsection{Geomagnetic activity}

In this section we present the results of comparison of the level of magnetic activity at Hornsund, Arctowski, and Belsk - another observatory of IG PAS. We assume that the activity at Świder is close to that at Belsk (BEL $20.80^{\circ} \mathrm{E}, 51.83^{\circ} \mathrm{N}$, geomagnetic latitude $\sim 50.4^{\circ} \mathrm{N}$ ) since the stations are at the distance of $50 \mathrm{~km}$. The magnetic latitude of Arctowski is close to the magnetic latitude of Belsk and Świder, where the influence of magnetospheric generator in the ground-based electric field is usually absent. Some effects can be present during geomagnetic storms (Nikiforova et al. 2005, Kleimenova et al. 2008, 2009, 2013; Michnowski et al. 2014) and therefore we estimate the possible level of this disturbance at ARC by comparing geomagnetic activity levels at the three sites.

The magnetic activity at Arctowski was measured over the period of April 1978 to December 1995. Szymański et al. (1980) describe the setup of the magnetic observations at the station. We use available geomagnetic data from the three stations over that period, published in Publications of the Institute of Geophysics Polish Academy of Sciences, Series C - "Geomagnetism" in the tables "Three-hour-range indices $\mathrm{K}$ and magnetic character figures C". The indices have been calculated as described in 

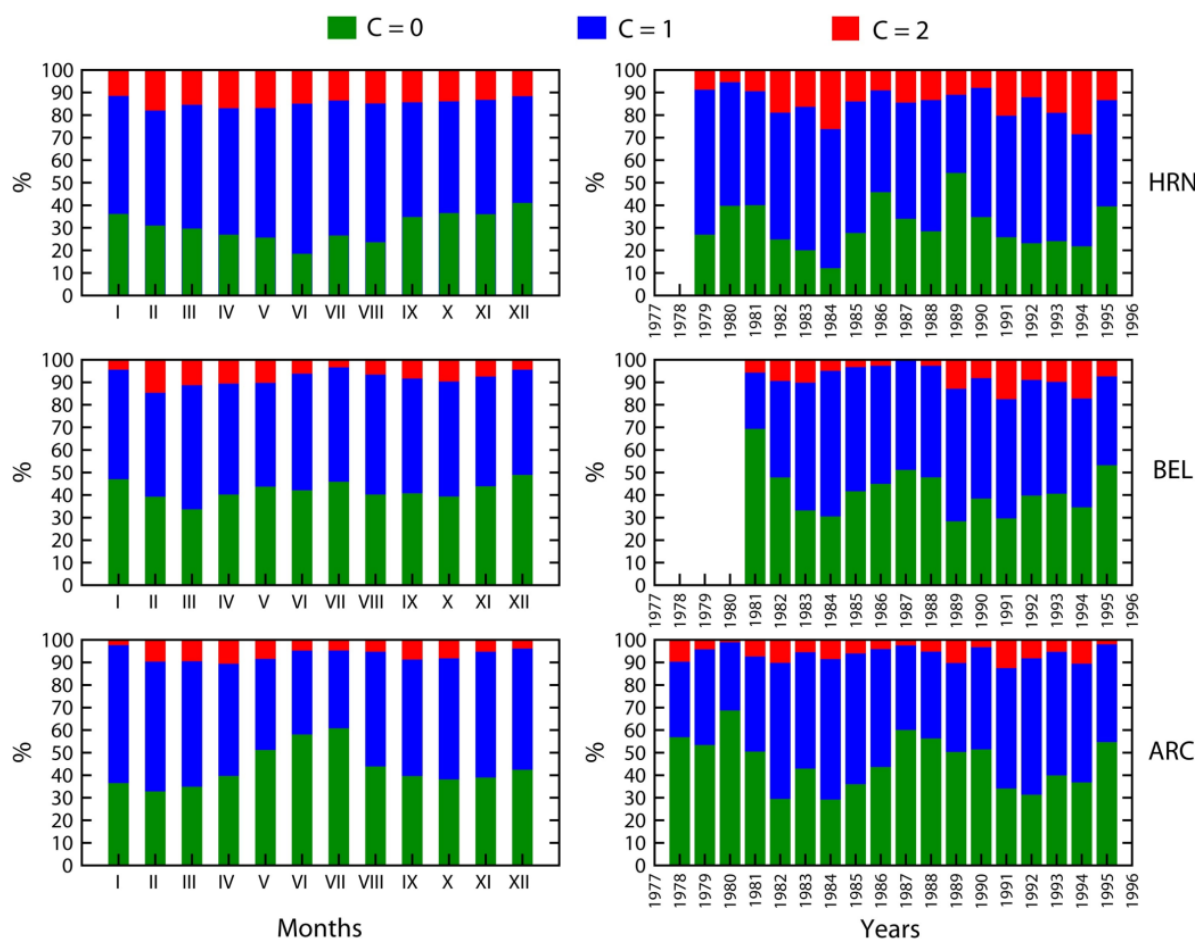

Fig. 2. Comparison of the geomagnetic activity at HRN, BEL, and ARC stations, based on the magnetic character figure $\mathrm{C}=0$ (weak), 1 (medium), 2 (strong). Left panels: Average variation of percentage of days characterized by $\mathrm{C}=0,1,2$ during a year. Right panels: percentage of days characterized by $\mathrm{C}=0,1,2$ over the period of magnetic observations at ARC (1979-1995). Month averages are based on 19811995 data.

Nowożynski et al. (1991). We perform simple comparison of the geomagnetic activity in terms of the magnetic character figure $\mathrm{C}$ (Fig. 2). We look at the average geomagnetic activity during a year (in each month), and the magnetic activity in each year of the considered period. A seasonal variation in the magnetic activity is always expected but the average levels are different.

In Arctowski the magnetic activity is overall comparable to Belsk station, although the Belsk station suffers from local artificial disturbance caused by railway which affects the number of magnetically quiet days (Neska et al. 2013). There is a small difference in the percentage of magnetically quiet days $(\mathrm{C}=0)$, i.e., $45 \%$ at $\mathrm{ARC}$ versus $42 \%$ at $\mathrm{BEL}$, and the percentage of strongly disturbed days is slightly greater, $8 \%$ at ARC versus $7 \%$ at BEL). On the other hand, Hornsund (magnetic latitude $\sim 73.8 \mathrm{~S}$ ) is most 
magnetically disturbed, with only $30 \%$ of magnetically quiet days and $15 \%$ of highly disturbed days. In historical reports we have not found evidence of aurora sightings directly from Arctowski; however, such events cannot be excluded. By private communications (Julita Biszczuk-Jakubowska and the station crew taking care of $\mathrm{AE}$ observations) we have established that, at least by eye, the aurora has not been observed in 2006 and between 2011 and 2015, but it is only from 2013 that the crew has been alerted to notify about such events if they were able to see the aurora. We conclude that the magnetic activity at Arctowski station is comparable to that of Świder, but Arctowski is more suitable for monitoring the global atmospheric electric circuit - GEC (Rycroft et al. 2000) than Świder, because, as opposed to Świder, the effects of aerosol and atmospheric turbulence at ARC can be neglected, as demonstrated by Kubicki et al. (2016). On the other hand, the weather conditions are not very favourable and the atmospheric electricity fair-weather criteria are rarely met. Nevertheless, Arctowski station can provide valuable recordings of fair-weather electric field for comparison with Świder observations, as presented in Section 5.

\subsection{Radioactivity}

According to geological research (Birkenmajer 1980) the South Shetland islands are of volcanic origin and therefore may contain radioactive elements that cause increased ground-level air ionisation. This may affect the measured electric field due to the formation of the so-called electrode layer. The present electric field measurements show that there is no effect of the electrode layer on the electric field; however, professional measurements of the radioactivity of the soil are planned in future.

\section{ATMOSPHERIC ELECTRIC FIELD AT ARCTOWSKI STATION}

Atmospheric electricity observations, i.e., of the atmospheric electric field have been performed at Arctowski Station for the first time. Figure 3 shows the electric field sensor and the container containing the data logger and power supply installed there in December 2012. Figure 4 shows the sensor's location, added to the schematic map of the station infrastructure from the paper on magnetic observations by Szymański (1980).

The electric field at the ground level is the superposition of electrical effects of global (main generators of the GEC) and local origin (meteorological phenomena, natural and anthropogenic aerosols) (Bennett and Harrison 2007). In Fig. 5 we present examples of electric field variations at Arctowski station in different weather conditions. In this paper we use the convention that the downward directed is positive - this is the direction the atmospheric electric field in fair-weather (atmospheric electricity convention) - 

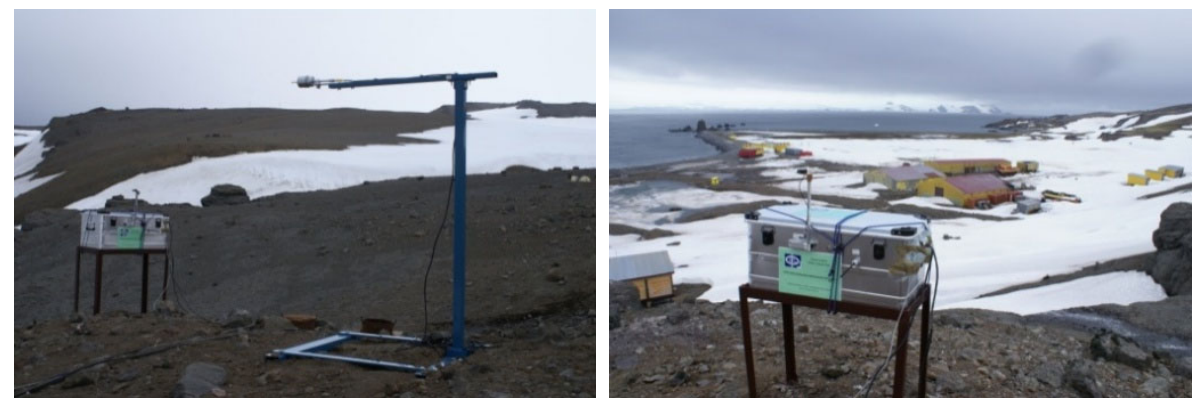

Fig. 3. Photographs of the electric field sensor and data acquisition system at Arctowski station, installed there in December 2012. Photography by Sylwia Łukawska.

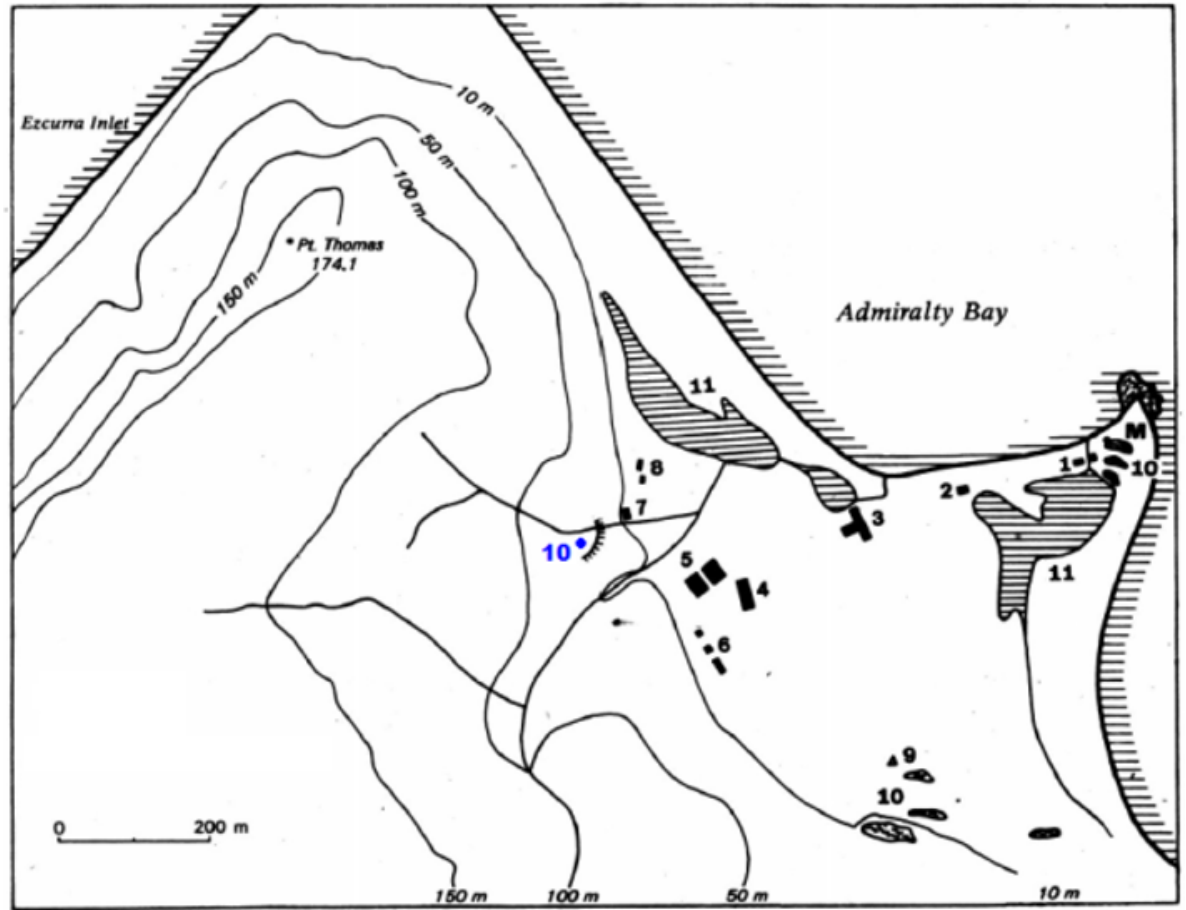

Situation of geophysical laboratory and magnetic pavilions in Polish Antarctic Station Arctowski

1-Biological laboratory, 2 - Meteorology - laboratory, 3 - Living house, 4 - Power station, 5-Magazines, 6 - Summer laboratories, 7 - Geophysical laboratory, 8 - Magnetic pavillions, 9 - Geodethic pillar, M-Azimuth mark 10 - Electric field sensor

Fig. 4. Schematic plan of the Arctowski station with added location of the electric field sensor (10 - blue point on the map). Adapted from Szymański (1980, Fig. 1). 

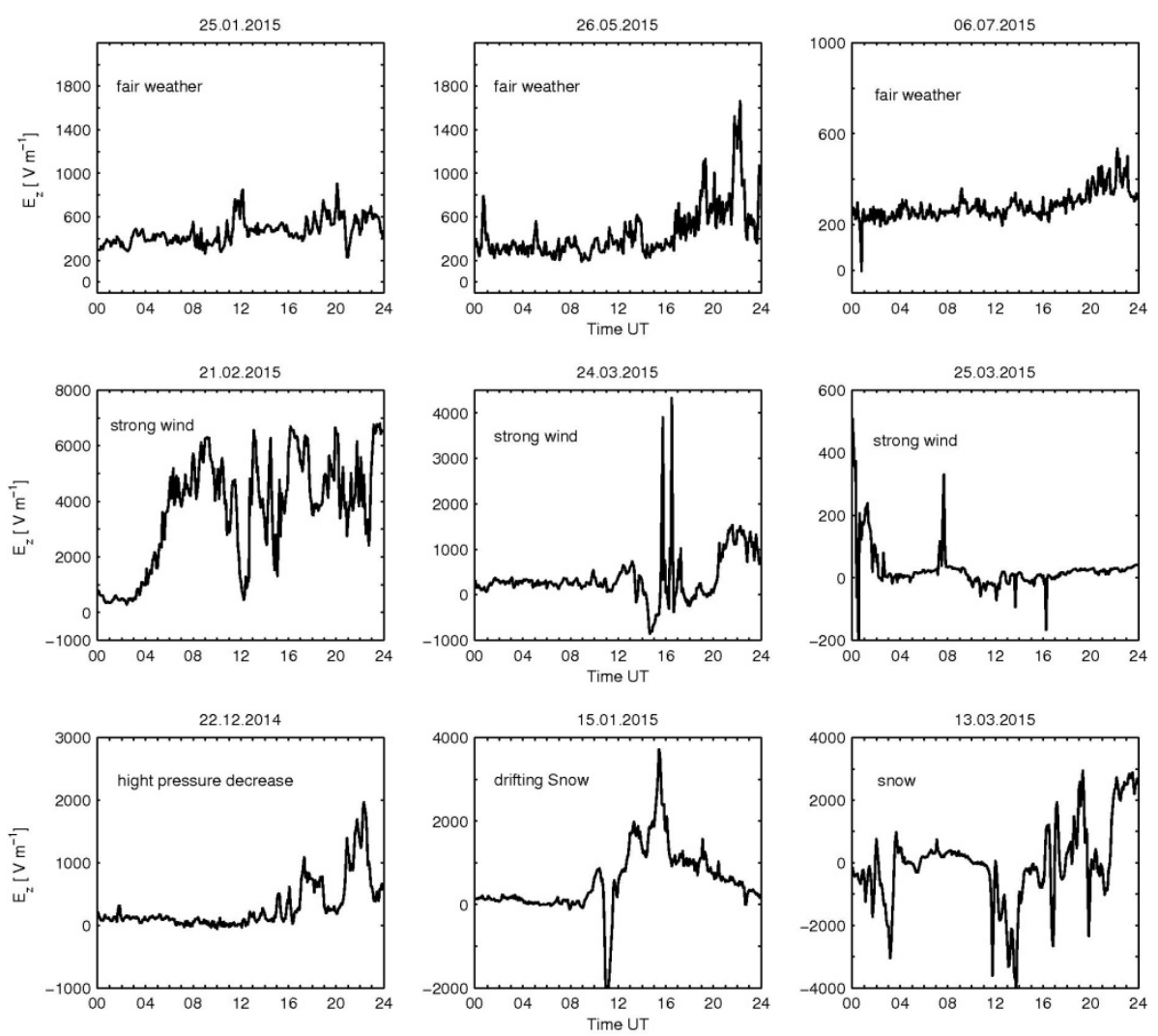

Fig. 5. Examples of diurnal variations of the ground-level electric field $E z$ measured at Arctowski station in 2013-2015. Values shown are not reduced to their groundlevel values.

physically the values we show are equivalent to the values of the vertical atmospheric electric potential gradient (physics sign convention). The criterion of fair weather allows to select data with minimal local effects (Fig. 5, upper row). Strong winds can cause transportation of space charge accumulated in the surface layer associated with the effect of electrode layer and subsequently a change in the electric field (Fig. 5, middle row). During rain or snow, the wind can cause the turbulence mixing of precipitation particles on which electric charge can be stored and this may result in positive or negative spikes in the measured field. The effect of low clouds, precipitation or fog may appear in the variation of the vertical electric field as mild or sudden change of the sign or amplitude or a pulse in the atmospheric electric field (Fig. 5, bottom row). 


\subsection{Diurnal fair-weather electric field variations}

In atmospheric electricity of great interest are diurnal variations of the electric field or electric current density in the conditions of fair weather. They are usually compared to the Carnegie curve which is the historical, average diurnal variation of the fair-weather atmospheric electric field derived from ocean measurements (Parkinson and Torreson 1931), and in the view of the global atmospheric circuit hypothesis (Wilson 1920) reflects the diurnal variation of electricity (from electrified clouds) in the atmosphere. It is believed that the average of the ocean measurements is free from factors which usually affect the field, depending on where it is measured and at what time, such as atmospheric convection, effect of aerosols, additional regional and local current generators. From this point of view the local conditions at Arctowski are moderate - the site is far from world thunderstorm activity centers and far from the normal range of the magnetospheric generator (as discussed in Section 4), atmospheric convection can sometimes occur there in the summer, for example on days with high difference of temperature between the ground and air - the temperatures at Arctowski station have been investigated by e.g. Kejna (1999), Kejna and Láska (1999), and more recently by Araźny et al. (2013).

Below we present an updated diurnal variation of the fair-weather electric field at Arctowski station. The new curve has been calculated on the basis of whole day diurnal variation of the electric field (00-24 UT) from 38 selected days of fair weather, from the three years of observations between 2013 and 2015, i.e., from the beginning of the electric field measurements (Table 1). We show the diurnal variation of hourly average mean (Fig. 6a) and medians (Fig. 6b) and the Carnegie curve (Fig. 6c) for comparison (values taken from Isräel 1970). The errors displayed in Fig. 6a are the standard deviations, in Fig. $6 \mathrm{~b}$ - the interquartile range determined by the first quartile from the bottom and the third quartile from the top. The difference between the third quartile and the median is usually larger than the difference between the median and first quartile which means that there are more values higher than the median value. This is not true particularly for 10 UT when lower values of the electric field occur more often at this hour - this is reflected in the mean average curve. Both curves have maximum at 1920 UT which usually corresponds with the maximum activity of the American thunderstorm centre. The correlation coefficient of the mean curve with the Carnegie curve is 0.75 , and of the median curve it is 0.61. Compared with the Carnegie curve the deviation of the curve's maximum from the average value of the curve $(300 \mathrm{~V} / \mathrm{m}$ - this value is not reduced to the value at ground level) is $14.2 \%$, while for the Carnegie curve it is $40 \%$. The average mean curve has a minimum between 10 and 13 UT, the median curve has a 


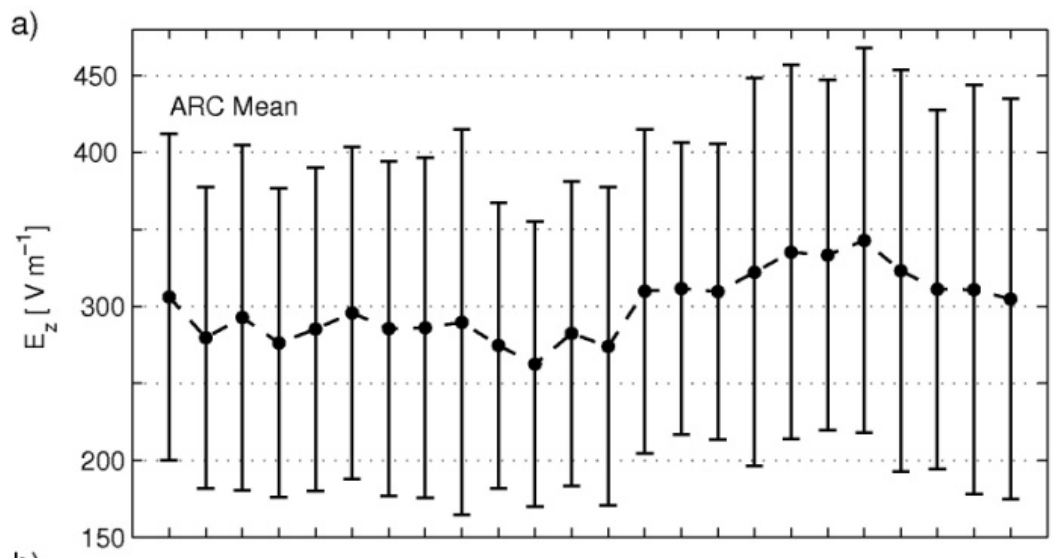

b)

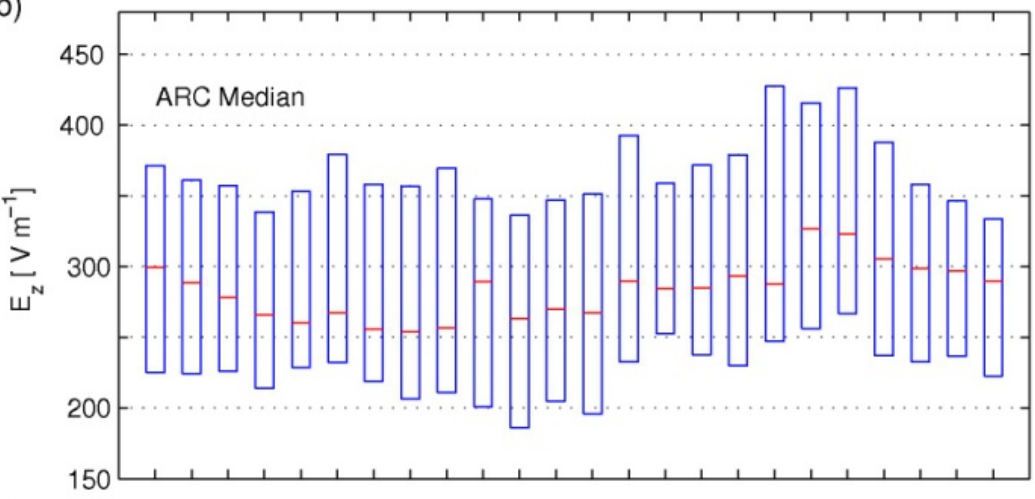

c)

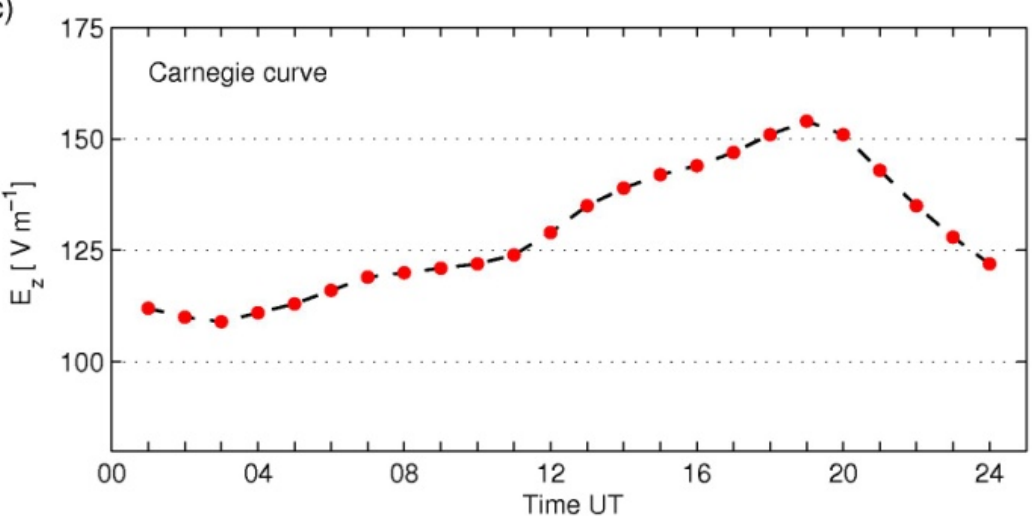

Fig. 6. Diurnal variation of the fair-weather atmospheric electric field $E_{z}$ at Arctowski station based on measurements from 2013-2015. Values shown are not reduced to their ground-level values. The field is positive in agreement with the atmospheric electricity sign convention. (a) Average mean curve with error bars as standard deviation, (b) Median curve and the quartile bar errors, (c) The Carnegie curve (Isräel 1970). 
Table 1

Analysis of atmospheric electricity fair-weather conditions at Arctowski station over the observation period from December 2013 to December 2015. The number of days fulfilling the criteria of fair weather (for at least half of the day) is given in the first column, days with high cloudiness (6-8), snow and strong wind - in the second, third, and fourth column, respectively.

\begin{tabular}{|c|c|c|c|c|}
\hline Month & $\begin{array}{c}\text { Fair } \\
\text { weather }\end{array}$ & $\begin{array}{c}\text { Cloudiness } \\
6-8 / 8\end{array}$ & $\begin{array}{l}\text { Snow, } \\
\text { drifting } \\
\text { snow }\end{array}$ & $\begin{array}{l}\text { Strong wind } \\
\text { diurnal mean } \\
\quad>10 \mathrm{~m} / \mathrm{s}\end{array}$ \\
\hline Jan 2013 & 2 & 27 & 2 & 2 \\
\hline Feb 2013 & 3 & 24 & - & 3 \\
\hline Mar 2013 & 4 & 20 & - & 4 \\
\hline Apr 2013 & 2 & 25 & - & 8 \\
\hline May 2013 & 2 & 28 & - & 2 \\
\hline Jun 2013 & 4 & 20 & - & 5 \\
\hline Jul 2013 & 3 & 25 & 3 & 3 \\
\hline Aug 2013 & 4 & 24 & 1 & 5 \\
\hline Sep 2013 & 3 & 26 & 5 & 2 \\
\hline Oct 2013 & 2 & 27 & - & 2 \\
\hline Nov 2013 & 2 & 28 & - & No data \\
\hline Dec 2013 & 1 & 25 & - & 1 \\
\hline 2013 Total & 32 & & & \\
\hline Jan 2014 & 1 & 28 & - & 1 \\
\hline Feb 2014 & 0 & 26 & - & 1 \\
\hline Mar 2014 & 1 & 30 & - & No data \\
\hline Apr 2014 & 4 & 24 & - & 5 \\
\hline May 2014 & 2 & 13 & - & 3 \\
\hline Jun 2014 & No data & No data & No data & 3 \\
\hline Jul 2014 & No data & No data & No data & 7 \\
\hline Aug 2014 & No data & No data & No data & 3 \\
\hline Sep 2014 & No data & No data & No data & 2 \\
\hline Oct 2014 & No data & No data & No data & No data \\
\hline Nov 2014 & 2 & 13 & - & 2 \\
\hline Dec 2014 & 2 & 18 & 1 & No data \\
\hline 2014 Total & 12 & & & \\
\hline Jan 2015 & 2 & 20 & 3 & 2 \\
\hline Feb 2015 & 3 & 23 & 4 & 4 \\
\hline Mar 2015 & 5 & 15 & 7 & 6 \\
\hline
\end{tabular}


Table 1 (continuation)

\begin{tabular}{|l|c|c|c|c|}
\hline Month & $\begin{array}{c}\text { Fair } \\
\text { weather }\end{array}$ & $\begin{array}{c}\text { Cloudiness } \\
6-8 / 8\end{array}$ & $\begin{array}{c}\text { Snow, } \\
\text { drifting } \\
\text { snow }\end{array}$ & $\begin{array}{c}\text { Strong wind } \\
\text { diurnal mean } \\
>10 \mathrm{~m} / \mathrm{s}\end{array}$ \\
\hline Apr 2015 & 3 & 21 & 2 & 1 \\
May 2015 & 4 & 26 & 4 & - \\
Jun 2015 & 5 & 22 & 2 & - \\
Jul 2015 & 12 & 19 & 2 & - \\
Aug 2015 & 9 & 18 & - & - \\
Sep 2015 & 3 & 23 & - & - \\
Oct 2015 & 4 & 20 & - & No data \\
Nov 2015 & 6 & No data & No data & No data \\
Dec 2015 & 4 & 13 & No data & 2 \\
2015 Total & $\mathbf{6 0}$ & & & - \\
May 2013 & 2 & 28 & &
\end{tabular}

minimum between 07 and 09 UT while the minimum of the Carnegie is at 03 UT. When compared with the diurnal variation from Świder (Kubicki et al. 2007) the Arctowski electric field curve has a minimum later than that of Świder (03-04 UT), and also different from the minimum of the Carnegie curve. At present it is difficult to judge whether this is because of local effects or global effects, which manifested themselves in this particular way.

\section{SUMMARY AND CONCLUSION}

Polish network of atmospheric electricity stations in three scientific observatories at PAS stations: Stanislaw Kalinowski Geophysical Observatory in Świder, Stanisław Siedlecki Polar Station in Hornsund and Henryk Arctowski Antarctic Station has been set up. Data from the network observation sites are organised in a database. The observation equipment is portable and allows easy installation of atmospheric electricity observations at other locations in future, especially at other sites in polar regions.

The atmospheric electricity observation programme is important for atmospheric electricity research and atmospheric physicists, particularly concerned with the Earth's global atmospheric electric circuit as it provides tools for the global circuit monitoring (Williams 2009). To considerable extent it can also be relevant in the studies of near-Earth environment and in meteorological studies, as the GEC is coupled to extra-terrestrial influences and has direct connections with the Earth's weather. Polish Antarctic stations, the Arctowski, and the A.B. Dobrowolski station located closer to the South Geomagnetic Pole, $100.75^{\circ} \mathrm{E}, 66.27^{\circ} \mathrm{S}$ (Gregorczuk 1980) and closed at present, are situated in locations which provide interesting opportunities 
for the development of atmospheric and solar-terrestrial research. The variations of the atmospheric electric field at Arctowski during fair-weather is a valuable addition to the monitoring of diurnal variations in the atmospheric electric circuit and monitoring of its generators. Data from the network can be used for global atmospheric electric circuit (GEC) studies and its diurnal, seasonal and long-term variations, validation of GEC models such as EGATEC (Odzimek et al. 2010), investigations of the electricity of clouds (Odzimek et al. 2014) and disturbances in fair-weather atmospheric electric field during events such as geomagnetic storms, Forbush decreases or solar proton events on atmospheric electricity at ground level (e.g., Kleimenova et al. 2009).

Acknowledgments. This work has been supported by Polish National Science Centre grant number NCN-2011/01/B/ST10/07118, awarded to the Institute of Geophysics of the Polish Academy of Sciences. Atmospheric electricity observations at Świder and Hornsund have been supported within the statutory activities of Institute of Geophysics PAS, grant No. 3841/E-41/S/2013 and No. 3841/E-41/S/2015 of the Ministry of Science and Higher Education of Poland. Credits are also to the Institute of Biochemistry and Biophysics of the Polish Academy of Sciences for providing access to the observation site and operating the measurements of the atmospheric ground-level electric field at the Henryk Arctowski Polish Antarctic Station, and for providing meteorological and aerosol concentration data. The authors would like to thank Maciej Benedyk, Mirosław Szumny, Piotr Łepkowski who performed the measurements at the Polish Polar Station in Hornsund, and Sylwia Łukawska, Emil Kasprzyk and Dawid Gajownik who performed the measurements at the Polish Arctowski Antarctic Station.

For the analysis of geomagnetic activity we used data from the following volumes of Publications of the Institute of Geophysics, Polish Academy of Sciences: Arctowski: volumes C-21 (181), C-22 (182), C-28 (202), C-32 (212), C-35 (225), C-44 (244), C-54 (276), C-60 (292), C-63 (300); Belsk C-8 (133), C-9 (139), C-10 (144), C-13 (159), C-17 (166), C-20 (180), C-23 (187), C-26 (196), C-29 (205), C-34(208), C-37 (227), C-38 (228), C-40 (240), C-45 (250), C-49 (259), C-51 (267), C-55 (298), C-58 (287); Hornsund: C-14 (163), C-27 (196), C-31 (210), C-43 (243), C-47 (254), C-48 (256), C-53 (273), C-57 (286), C-64 (301). We thank Danuta Jasinkiewicz from the Geophysical Observatory in Swider for her help in digitalisation of the magnetic data from paper publications. 


\section{References}

Angiel, P.J., M. Potocki, and J. Biszczuk-Jakubowska (2010), Weather condition characteristics at the H. Arctowski Station (South Shetland Islands, Antarctica) for 2006, in comparison with multi-year research results, Misc. Geogr. 14, 79-89.

Araźny, A., M. Kejna, and I. Sobota (2013), Ground temperature at the Henryk Arctowski Station (King George Island, Antarctic) - Case study from the period January 2012 to February 2013, Bull. Geogr., Phys. Geograph. 6, 1, 59-80, DOI: 10.2478/bgeo-2013-0004.

Bennett, A.J., and R.G. Harrison (2007), Atmospheric electricity in different weather conditions, Weather 62, 10, 277-283, DOI: 10.1002/wea.97.

Bering III, E.A., J.R. Benbrook, G.J. Byrne, and A.A. Few (1991), Measurements of vertical atmospheric electric current at a network of sites in Antarctica including manned stations and automatic geophysical observations. In: Proc. the International Workshop on Global Atmospheric Electricity Measurements, S. Michnowski and L.H. Ruhnke (eds.), Publs. Inst. Geophys. Pol. Acad. Sci. D-35, 238, 119-135.

Berliński, J., G. Pankanin, G. and M. Kubicki (2007), Large scale monitoring of troposphere electric field. In: Proc. 13th Int. Conf. Atmospheric Electricity, 13-18 August 2007, Beijing, China, 124-126.

Birkenmajer, K. (1980), Report on geological investigations of King George Island, South Shetland Islands (West Antarctica) in 1978/79, Stud. Geol. Pol. 64, 89-105 (in Polish).

Burns, G.B., M.H. Hessea, S.K. Parcella, S. Malachowski, and K.D. Coleb (1995), The geoelectric field at Davis station, Antarctica, J. Atmos. Sol. Terr. Phys. 57, 14, 1783-1797, DOI: 10.1016/0021-9169(95)00098-M.

Cobb, W.E. (1976), Atmospheric Electric Measurements at the South Pole. In: H. Dolezalek, R. Reiter, and H. Landsberg (eds.), Proc. 5th Int. Conf. on Atmospheric Electricity, Electrical Processes in Atmospheres, 2-7 September 1974, Garmisch-Partenkirchen, Germany, 161-167, DOI: 10.1007/9783-642-85294-7 23.

Cygan, B. (1981), Characteristics of meteorological conditions at the Arctowski Station during the summer season of 1979-1980, Pol. Polar Res. 2, 3-4, 35-46.

Deshpande, C.G., and A.K. Kamra (2001), Diurnal variations of the atmospheric electric field and conductivity at Maitri, Antarctica, J. Geophys. Res. 106, D13, 14207-14218, DOI: 10.1029/2000JD900675.

Dziembowska, A. (2009), Eighty years of fair-weather atmospheric electricity monitoring in Poland. In: P. Baranski and M. Kubicki (eds.), Recent developments in Atmospheric Electricity, Publs. Inst. Geophys. Pol. Acad. Sci. D73, 412, 9-14.

Dungey, J.W. (1961), Interplanetary magnetic field and the auroral zones, Phys. Rev. Lett. 6, 2, 47-48, DOI: 10.1103/PhysRevLett.6.47. 
Frank-Kamenetsky, A.V., G.B. Burns, O.A. Troshichev, V.O. Papitashvili, E.A. Bering, and W.J.R. French (1999), The geoelectric field at Vostok, Antarctica: its relation to the interplanetary magnetic field and the cross polar cap potential difference, J. Atmos. Sol. Terr. Phys. 61, 18, 13471-1356, DOI: 10.1016/S1364-6826(99)00089-9.

Frank-Kamenetsky, A.V., O.A. Troshichev, G.B. Burns, and V.O. Papitashvili (2001), Variations of the atmospheric electric field in the near-pole region related to interplanetary magnetic field, J. Geophys. Res. 106, A1, 179-190, DOI: $10.1029 / 2000 J A 900058$.

Frank-Kamenetskii, A.V., A.L. Kotikov, A.A. Kruglov, G.B. Burns, N.G. Kleimenova, O.V. Kozyreva, M. Kubitski, and A. Odzimek (2012), Variations in the near-surface atmospheric electric field at high latitudes and ionospheric potential during geomagnetic perturbations, Geomagn. Aeron. 5, 52, 629-638, DOI: 10.1134/S0016793212050064.

Gregorczuk, M. (1980), Climate of Bunger Oasis (region of A.B. Dobrowolski Station, Antarctic), Pol. Polar Res, 1, 4, 205-230.

Isräel, H. (1970), Atmospheric Electricity, Vol. 1, Fundamentals, Conductivity, Ions, Israel Program for Scientific Translations, Jerusalem, $317 \mathrm{pp}$.

Kejna, M. (1999), Air temperature on King George Island, South Shetland Islands, Antarctica, Pol. Polar Res. 20, 3, 183-201.

Kejna, M., and K. Láska (1999), Spatial differentiation of ground temperature in the region of Arctowski Station, King George Island, Antarctica, Pol. Polar Res. 20, 3, 221-241.

Kleimenova, N.G., O.V. Kozyreva, S. Michnowski, and M. Kubicki (2008), Effect of magnetic storms in variations in the atmospheric electric field at midlatitudes, Geomagn. Aeron. 48, 5, 622-630, DOI: 10.1134/S0016793208050 071.

Kleimenova, N., O. Kozyreva, M. Kubicki, and S. Michnowski (2009), Variations of the mid-latitude atmospheric electric field (Ez) associated with geomagnetic disturbances and Forbush decreases of cosmic rays. In: P. Baranski and M. Kubicki (eds.), Recent developments in Atmospheric Electricity, Publs. Inst. Geophys. Pol. Acad. Sci. D-73, 412, 55-64.

Kleimenova, N.G., O.V. Kozyreva, M. Kubicki, and S. Michnowski (2010), Morning polar substorms and variations in the atmospheric electric field, Geomagn. Aeron. 50, 1, 48-57, DOI: 10.1134/S0016793210010068.

Kleimenova, N.G., O.V. Kozyreva, M. Kubicki, and S. Michnowski (2011), Variations in the near-ground electric field at high latitudes and the potential drop across the polar cap during morning polar substorms, Geomagn. Aeron. 51, 3, 394-401, DOI: 10.1134/S0016793211030091.

Kleimenova, N.G., O.V. Kozyreva, M. Kubicki, A. Odzimek, and L.M. Malysheva (2012), Effect of substorms in the Earth's nightside sector on variations in the surface atmospheric electric field at polar and equatorial latitudes, Geomagn. Aeron. 52, 4, 467-473, DOI: 10.1134/S001679321204007X. 
Kleimenova, N.G., O.V. Kozyreva, S. Michnowski, and M. Kubicki (2013), Influence of geomagnetic disturbances on atmospheric electric field (Ez) variations at high and middle latitudes, J. Atmos. Sol.-Terr. Phys. 99, 117-122, DOI: $10.1134 / \mathrm{S} 0016793212050064$.

Kozyreva, O.V., N.N. Nikiforova, N.G. Kleimenova, S. Michnowski, and M. Kubicki (2007), Electric air-Earth vertical current pulsations at Hornsund during polar substorms. Case studies, In: Proc. 13th Int. Conf. on Atmospheric Electricity, 13-18 August 2007, Beijing, China, Vol. 1, 29-33.

Kubicki, M., S. Michnowski, B. Myslek-Laurikainen, and S. Warzecha (2003) Long term variations of some atmospheric electricity, aerosol, and extraterrestrial parameters at Świder Observatory. In: Proc. 12th Int. Conf. on Atmospheric Electricity, 9-13 June 2003, Versailles, France, Vol. 1, 291-294.

Kubicki, M., S. Michnowski, and B. Myslek-Laurikainen (2007), Seasonal and daily variations of atmospheric electricity parameters registered at the Geophysical Observatory at Świder (Poland) during 1965-2000. In: Proc. 13th Int. Conf. on Atmospheric Electricity, 13-18 August 2007, Beijing, China, 5053.

Kubicki, M., A. Odzimek, N.G. Kleimenova, O.V. Kozyreva, and M. Neska (2014), Synchronisation of main Global Electric Circuit generators from groundlevel electric field Ez at three distant locations on the globe at middle and high latitudes. In: Proc. 15th Int. Conf. on Atmospheric Electricity, 15-20 June 2014, Norman, USA, 9 pp.

Kubicki, M., A. Odzimek, and M. Neska (2016), Relationship of ground-level aerosol concentration and atmospheric electric field at three observation sites in the Arctic, Antarctic and Europe, Atmos. Res. 178-179, 329-346, DOI: 10.1016/j.atmosres.2016.03.029.

Lessard, M.R., A.J. Gerrard, and A.T. Weatherwax (eds.) (2014), Solar-terrestrial research in polar regions: past, present, and future. In: Proc. Polar Research Meeting, 12-13 November 2012, University of New Hampshire, USA, $64 \mathrm{pp}$.

Machowski, J. (1998a), Henryk Arctowski (1871-1958), Pol. Polar Res. 19, 1-2, 7 10.

Machowski, J. (1998b), Contribution of H. Arctowski and A. B. Dobrowolski to the Antarctic Expedition of Belgica (1897-1899), Pol. Polar Res. 19, 1-2, $15-$ 30 .

Michnowski, S., A. Szymanski, and N.N. Nikiforova (1991), On simultaneous observations of geomagnetic and atmospheric electric field changes in Arctic station Hornsund, Spitsbergen. In: S. Michnowski and L. H. Ruhnke (eds.), Proc. Int. Workshop on Global Atmospheric Electricity Measurements, 1016 September 1989, Mądralin, Poland, Publ. Inst. Geophys. Pol. Acad. Sci. D-35, 238, 83-96.

Michnowski, S., N.N. Nikiforova, and N.G. Kleimenova (1996), The response of the ground-level electric field at Hornsund to magnetospheric-ionospheric 
events. In: Proc. 10th Int. Conf. on Atmospheric Electricity, 19-24 June 1996, Osaka, Japan, 520-523.

Michnowski, S. (1998), Solar wind influences on atmospheric electricity variables in polar regions, J. Geophys. Res. 103, D12, 13939-13948, DOI: 10.1029/ 98JD01312.

Michnowski, S., M. Kubicki, J. Drzewiecki, S. Israelsson, N. Kleimenova, N. Nikiforova, and O. Kozyreva (2003), Variations of atmospheric electricity elements in polar regions related to the solar wind changes, In: Proc. 12th Int. Conf. in Atmospheric Electricity, 9-13 June 2003, Versailles, France, Vol. 1, 295-296.

Michnowski, S., M. Kubicki, N.G. Kleimenova, N.N. Nikiforova, O.V. Kozyreva, and S. Israelsson (2007), The polar ground-level electric field and current variations in relation to solar wind changes. In: Proc. 13th Int. Conf. on Atmospheric Electricity, 13-18 August 2007, Beijing, China, Vol. 1, 9-12.

Michnowski, S., A. Odzimek, N.G. Kleimenova, O.V. Kozyreva, M. Kubicki, and N.N. Nikiforova (2014), Review of examples of solar wind lower atmosphere coupling observed in the electric field (Ez) variations at the Earth's surface during magnetic storms (2014). In: Proc. 15th Int. Conf. on Atmospheric Electricity, 15-20 June 2014, Norman, USA, 8 pp.

Neska, A., J. Reda, M. Neska, and Y. Sumaruk (2013), On the influence of DC railway noise on variation data from Belsk and Lviv Geomagnetic Observatories, Acta Geophys. 61, 2, 385-403, DOI: 10.2478/s11600-012-0058-0.

Nikiforova, N.N., N.G. Kleimenova, O.V. Kozyreva, M. Kubicki, and S. Michnowski (2005), Unusual variations in the atmospheric electric field during the main phase of the strong magnetic storm of October 30, 2003, at Świder Polish midlatitude Observatory, Geomagn. Aeron. 45, 1, 140-144.

Nowożynski, K., T. Ernst, and J. Jankowski (1991), Adaptive smoothing method for computer derivation of K-indices, Geophys. J. Int. 104, 1, 85-93, DOI: 10.1111/j.1365-246X.1991.tb02495.x.

Odzimek, A., and M. Lester (2009), Modelling the Earth's global atmospheric electric circuit - development, challenges and directions. In: P. Baranski and M. Kubicki (eds.), Recent developments in Atmospheric Electricity, Publs. Inst. Geophys. Pol. Acad. Sc. D-73, 214, 37-54.

Odzimek, A., M. Lester, and M. Kubicki (2010), EGATEC: A new high-resolution engineering model of the global atmospheric electric circuit. 1. Currents in the lower atmosphere, J. Geophys. Res. 115, D18207, DOI: 10.1029/ 2009JD013341.

Odzimek, A., M. Kubicki, M. Lester, and A. Grocott (2011), Relation between the SuperDARN ionospheric potential and ground electric field at polar station Hornsund. In: Proc. 14th Int. Conf. on Atmospheric Electricity, 7-12 August 2011, Rio de Janeiro, Brazil, 4 pp.

Odzimek, A., M. Kubicki, and P. Baranski (2014), Ground-level atmospheric electricity under low-level stratiform clouds. In: Proc. 15th Int. Conf. on Atmospheric Electricity, 15-20 June 2014, Norman, USA, 7 pp. 
Park, C.G. (1976a), Solar magnetic sector effects on the vertical atmospheric electric field at Vostok, Antarctica, J. Geophys. Res. 3, 8, 475-478, DOI: 10.1029/ GL003i008p00475.

Park, C.G. (1976b), Downward mapping of high-latitude ionospheric electric fields to the ground, J. Geophys. Res. 81, 1, 168-174, DOI: 10.1029/ JA081i001p00168.

Parkinson, W.C., and O. Torreson (1931), The diurnal variation of the electric potential of the atmosphere over the ocean, Int. Union Terrest. Magn. Electr. Bull. 8, 340-345.

Rakusa-Suszczewski, S. (1977), Henryk Arctowski Antarctic Station of Polish Academy of Sciences, Nauka Polska 11-12, 103-114 (in Polish).

Rakusa-Suszczewski, S. (1980), III Antarctic Expedition to Arctowski Station (November 1978 - May 1979), Pol. Polar Res. 1, 1, 127-146 (in Polish).

Reddell, B.D., J.R. Benbrook, E.A. Bering, E.N. Cleary, and A.A. Few (2004), Seasonal variations of atmospheric electricity measured at Amundsen-Scott South Pole Station, J. Geophys. Res. 109, A09308, DOI: 10.1029/ 2004JA010536.

Rycroft, M.J., S. Israelsson, and C. Price (2000), The global atmospheric electric circuit, solar activity and climate change, J. Atmos. Sol.-Terr. Phys. 62, 1718, 1563-1576, DOI: 10.1016/S1364-6826(00)00112-7.

Szymański, A. (1980), The construction and work of magnetic observatory "Arctowski" (King George Island, South Shetland Islands), Pol. Polar Res. 1, 23, 105-115.

Tinsley, B.A., W. Liu, R.P. Rohrbaugh, and M.W. Kirkland (1998), South Pole electric field responses to overhead ionospheric convection, J. Geophys. Res. 103, D20, 26137-26146, DOI: 10.1029/98JD02646.

Wilson, C.T.R. (1920), Investigation on lightning discharges and on the electric field of thunderstorms, Phil. Trans. A 21, 73-115.

Williams, E.R. (2009), The global electrical circuit: a review, Atmos. Res. 91, 2-4, 140-152, DOI: 10.1016/j.atmosres.200805.018.

Received 24 February 2016

Received in revised form 1 July 2016

Accepted. 23 August 2016 